\title{
Plant Collecting with INPA
}

\author{
Ghillean T. Prance \\ B. A. Krukoff Curator of Amazonian Botany, \\ The N. Y. Botanical Garden
}

You can perhaps imagine my surprise when, returning to INPA after just over a year away from Manaus, I found a new campus just about to open. My congratulations to INPA on your rapid progress with the building and development program. Soon after I arrived in Manaus on January 14th 1971 the botany section and the herbarium were moved to their new buildings so that I have been able to use and enjoy these new facilities right from the start. 1971 was the third field work year for the New York Botanical Garden-INPA joint collecting program entitled a plant survey of Brazilian Amazonia. During the year we collected considerably in the vicinity of Manaus, and carried out 5 major expeditions to the interior in spite of the many adventures which befell our team. The 5 main expeditions are summarized below.

I. Western Roraim Territory. (February - March 27)

1. Participants: Ghillean T. Prance, William C. Steward (Kalamazoo College, Michigan, U.S.A.), José F. Ramos (IPEAN, Belém Pará), Osmarino P. Monteiro (INPA).

2. Localities visited: Serra dos Surucucus along trail to the Rio Uraricoera at Uaicá, also Rio Mucajai in the vicinity of Posto Mucajai Mission.

3. NUMBER OF HERBARIUM COLLECTIONS : 917.

4. Discussion: The expedition flew to Serra dos Surucucus where we picked up 19 indian porters under the leadership of Missionary Fritz P. Harter, who accompanied us as interpreter and guide. We then walked along the $280 \mathrm{~km}$ trail to the Rio Uraricoera passing through 6 almost unvisited Uaicá indian villages.
Following this we ascended the Rio Uraricoera to Uaicá airstrip to await on-going air transport. The plane which came to fetch us crash landed at Uaicá, and we were stranded for 10 days without food. We were able to live off the land until further transport arrived, eating mainly piranha fish, pupunha palm fruit and the fruit of Belucia sp. (Melastomaceae). Finally we flew on to Mucajai airstrip where we collected for another 2 weeks before returning to Manaus.

\section{WeStern ACRE (April 12 - May 25)}

1. Participants: Ghillean T. Prance, William C. Steward, Klauss Kubitzki (Institute for Systematic Botany, München, W. Germany), Paul J. M. Maas (Bctanical Museum and Herbarium, Utrecht, Netherlands), José F. Ramos, João F. Lima (INPA).

2. Localities visited: Cruzeiro do Sul, Rio Moa, Serra de Moa, Rio Juruá, Rio Juruá-Mirim.

3. NUMBER OF HERBARIUM COLLECTIONS : 1553.

4. Discussion: The expedition flew to Cruzeiro do Sul where we rented a house as headquarters. We collected in the vicinity of Cruzeiro do Sul and then ascended the Rio Moa in a rented launch and a small inflatable speed boat, as far as Serra de Moa. We collected extensively around the Serra and the inflatable boat was kept busy ferrying plants back to Cruzeiro do Sul. We returned to Cruzeiro do Sul and Maas led a second expedition to the lower Rio Juruá-Mirim. The Acre expeditions were excellent for collecting since the forest was in full flower at that time. We had one misadventure when João Lima was hit by a tree which he was felling and which broke his leg. 
III. RIOS PURUS, ITUXI AND CURUQUETÊ, Amazonas (July 16 - August 8)

1. PARTICIPANTS: Ghillean T. Prance, William C. Steward, Klaus Kubitzki, Paul J. Maas, Alan A. Atchiey (University of Maryland, U.S.A.) ; David B. Woolcott (University of New Mexico, U.S.A.); José F. Ramos, Osmarino P. Monteiro, Dionisio F. Coêlho (IUPA).

2. Localitins Visited: Rio Purus from the mouth to Lábrea, Rio Ituxi to Bôca de Curuquetê, Rio Curuquetê to headwaters.

\section{NUMBER OF HERBARIUM COLLECTIONS :} 1213.

4. DIscussion: The expedition ascended the Rio Purus as far as Lábrea in a rented launch, but also used its 3 inflatable boats for collecting along the banks. We spent 2 weeks based in Lábrea where we divided into 3 groups, one led by Maas, collecting and making a vegetation analysis of the Puciari Savannas, the second, led by Prance, visiting the village of the Jamamadi indians to collect their economic plants; the third, led by Atchley collecting around Lábrea concentrating on the Bignoniaceae. Following this we ascended the Rio Ituxi to Bôca do Curuquetê using all 3 inflatable boats. After collecting in the vicinity of Bôca do Curuquetê we continued up the Rio Curuquetê and camped and collected beside all four major falls on the river. At the third falls we sent one boat with 4 men back to Lábrea earlier than planned as Atchley became sick. The other boats continued to the end of the river where we proceeded to cross the watershed to the Rio Madeira at Abunã, using a mule train to help with baggage. Since 8 out of the 10 of us developed malaria our plans to return and collect on the Rio Madeira were cancelled, but not before we had made a large and significant collection from Lábrea and on the Rio Curuquetê. A ward of caution to future expeditions in the Rio Purus and Rio Ituxi region: Malaria is resistant to the conventional prophylactic drugs,

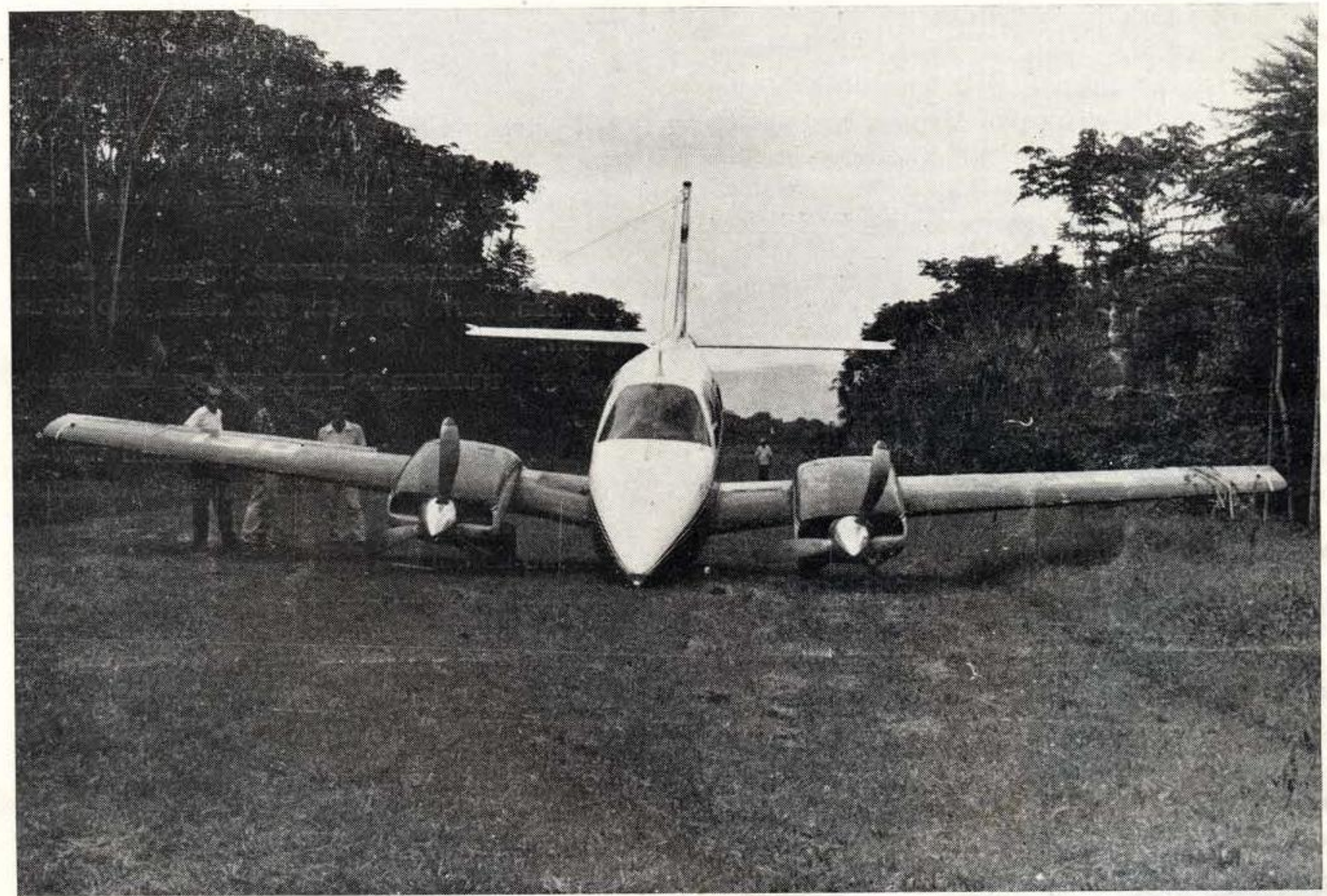

Photo 1 - The plane which crash landed at Uiacá will never be able to fly again 
and did not respond to treatment by chloroquin. camoquin and primaquin. Expedition members were found to have both Plasmodium vivax and P. falciperum.

\section{RIO NEGRo}

1. PARTICIPANTS: Ghillean T. Prance, Paul J. M. Maas, David B. Woolcott, José F. Ramos, Dionisio F. Coêlho and Osmarino P. Monteiro.

2. LOCALITIES Visited: Rio Negro from Manaus to Uaupés, Tapuruquara, Serra de Curicuriari, Rio Uneiuxi.

3. NUMBER OF HERBARIUM COLLECTIONS : 1227.

4. DIscussion: The expedition ascended the Rio Negro to Tapuruquara in a rented river launch. We made our headquarters in Tapuruquara and collected extensively in the vicinity of that town. We made a trip by inflatable boat to the Makú indian village on the Rio Uneiu- xi. We made a good collection of Makú indian medicinal plants as well as a general collection from the forests and Savannas along the river. We followed this by a 10 day trip by inflatable boats to Uaupés where we collected in the Caatinga forest and climbed Serra Curucuriari. Dionisio Coêlho was forced to leave the expe dition at Tapuraquara after being hit on the head by a falling branch. Fortunately his injuries did not prove to be too serious, and the mission hospital in Tapuruquara gave excellent care until he was flown out.

\section{Deni, Rio Cunhú́}

1. PARTICIPANTS: Ghillean T. Prance, Paul J. M. Maas, David B. Woolcott, Paul Moran (Summer Institute of Linguistics, Great Britain), José F. Ramos, Osmarino P. Monteiro.

2. Localities Visited: Rio Purus from mouth to Rio Tapauá, lower Rio Tapauá, Rio Cunhuá to Deni indian village, $6^{\circ} 43^{\prime} \mathrm{S}$; $66^{\circ} 47^{\prime} \mathrm{W}$.

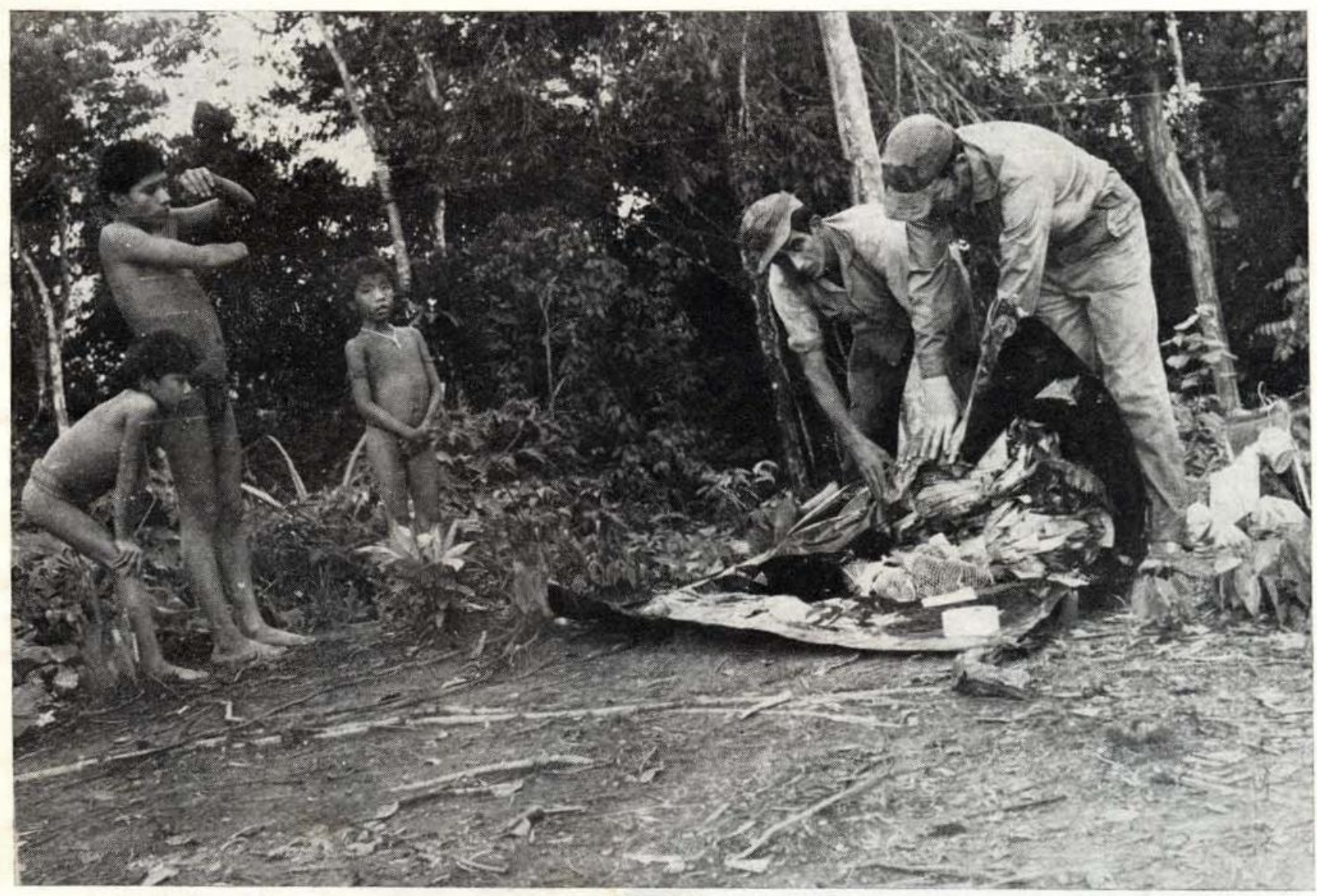

Photo 2 - Watched by Uaicá indians Prance and Osmarino wrap specimens in plastic together with formaldehyde preservative for shipment to Manaus 
3. NUMBER OF HERBARIUM COLLECTIONS : 255.

4. Discussion: The expediton left Manaus in the INPA launch-laboratory the Marupiara. We travelled in the launch to the mouth of the Rio Tapaua and from there ascended the Rio Cunhuá 20 hours in our largest inflatable. The object of this trip was to collect the economic plants of the Deni indians. We made an interesting collection of many of their economic plants including a contraceptive, and then returned to Manaus rapidly when Prance was called to England to visit his sick mother. Two of us returned from Deni to Manaus in 4 days by inflatable boat. This expedition was greatly helped by Moran who works amongst the Deni indians and who came as our guide and interpreter.

\section{THE RESULTS}

6070 herbarium collections were made in replicate sets of 12 where possible. Sets were deposited at INPA (the first set including all unicate collections), at the Museu Goeldi, Belém, and at the Museu Nacional, Rio de Janeiro, the other 9 sets were shipped to New York for identification and distribution. In addition a large number of collections of correlated wood samples, flowers in preservative and seeds were made. Economic plants from four tribes of indians, Uaicá, Jamamadi, Makú, and Deni were made for ethnobotanical studies. The various participating scientists were able to make special collections and field studies of the plant families of particular interest to them, i.e. Prance: Chrysobalanaceae, Caryocaraceae and Lecythidaceae. Maas: Zingiberaceae and Marantaceae. Kubitzki : Dilleniaceae, Guttiferae and Lauraceae. Atchley: Biognoniaceae. We also made special collections requested by several plant specialists from different countries.

\section{INPA AS A BASE}

INPA is proving an ideal headquarters for

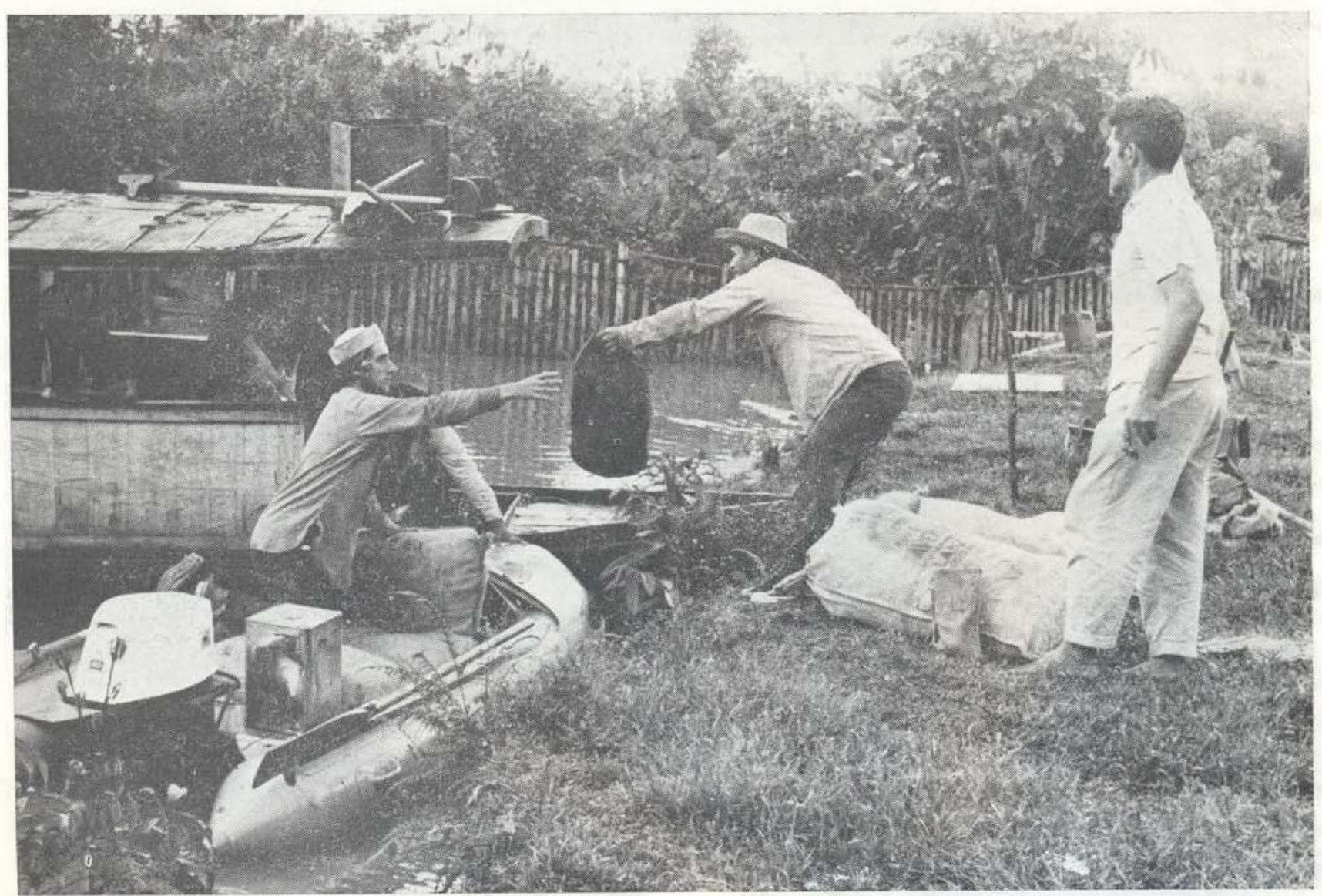

Photo 3 - Steward loading the expeditions smallest inflata: 'e hort with specimens at Serra de Moa 
field work in Amazonia. Geographically well situated, it is also a rapidly developing modern scientific institute. We were all impressed by the rapid changes and progress of INPA during the last 2 years, and our 1971 field work yielded greater results largely because of the improvements in INPA.

I was most impressed by the rapid action by the Director when anything needed to be done. For example during the early months of the year members of our team discovered an extremely interesting and important tract of vegetation on the Manaus-Caracarai road. We suggested to the Director that this would make a good reserve and that it should definitely be preserved from the destruction that follows a road. A month before we left Manaus we learned that this ground was inaugurated as a new INPA forest reserve with full government permission for its protection and use as a reserve. This just showed us that action is now a reality at INPA.
We were impressed by the new INPA floating-laboratory, the Marupiara. The facilities offered on board this boat are invaluable both to scientists at INPA and to visitors. With the use of the Marupiara we can achieve so much more than in the past. We were also glad to see the rigid maintainance schedule of the boat and the strict discipline and adherence to the rules by the crew. This will enable people to use the launch for many years to come.

Most of our team felt that INPA needs an assistant to the administrator to relieve the overburdened administrator. The long waits we all had for business affairs such as customs, shipping, mail, etc., could be avoided if the administrator had an assistant specializing in the needs of visiting scientists. The administrator was extremeiy helpful to us and we are grateful for all he did for us and are not criticizing him in the least because we can see how hard he has to work and often felt ashamed to

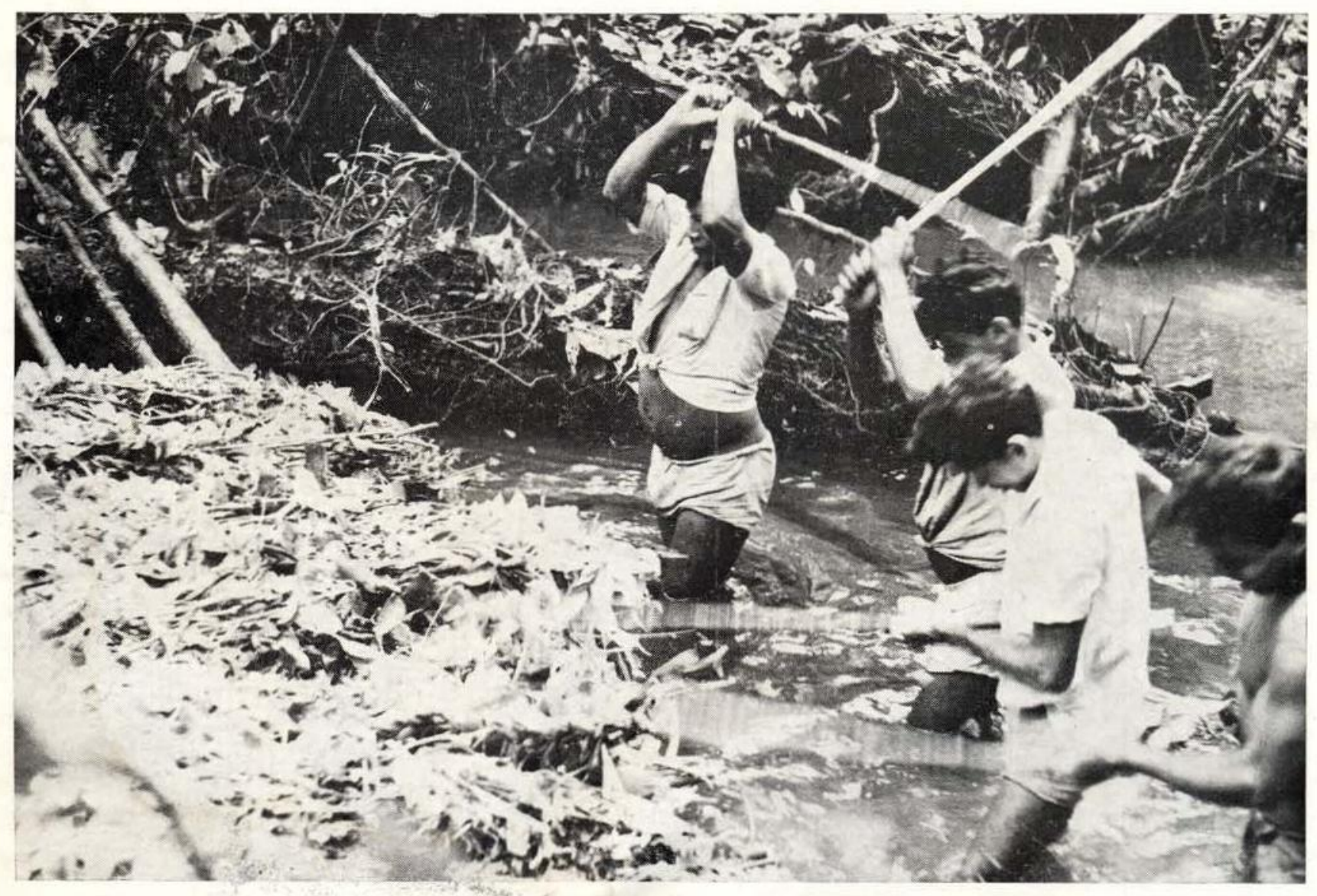

Photo 4 - A Makú indian fish poisoning outing. The indians are beating the juice out of the poison plant into the water of a small stream. 
bother him with the numerous small chores which inevitably arise in any overseas visitors program.

At this time of rapid development in Amazonia the need for conservation of the environment is urgent. The new roads such as the Trans-Amazon highway, the Manaus-Porto Velho highway and many others are essential and excelent for the development of the region. However, unless an enlightened conservation program is also in operation vast tracts of land will be rendered virtually useless by slash and burn agriculture. The Amazon is the greatest oxygen reserve which the world has; it is also full of natural resources that can be exploited without complete destruction of the environment. Since INPA is the leading Scientific Institute in this region it should be giving a firm lead in its development. Scientists, and especially biologists at INPA must be conservation minded in order for the region to survive the axe, the bulldozer and the exploiter. As a conclusion I would make a plea to INPA to look ahead to the future of Amazonia in light of conservation. Let us apply the lessons taught us by the mistakes of other regions where conservation started too late. Let us place a special conservation emphasis in our research and in our influence in the community. Perhaps then INPA will be known as the institute that saved Amazonia.

\section{ACKNOWLEDGEMENTS}

The field program was financed in greater part by a grant, GB-18655, from the National Science Foundation. We would all like to express our sincere thanks to the Director of INPA and to the many members of his staff who gave us so much help throughout the year, without which our work would have been impossible. 